\title{
The Relationships among Teacher Leadership, Teacher Self-Efficacy and Teacher Performance
}

\section{Öğretmen Liderliği, Öğretmen Öz Yeterliliği ve Öğretmen Performansı Arasındaki İlişkiler}

\author{
Yener AKMAN*
}

Received: 01 May 2021

Research Article

Accepted: 29 September 2021

ABSTRACT: This study examined the relationships among teacher leadership, teacher self-efficacy and teacher performance according to teachers' views. The participants of the study were 401 teachers working in the state (K12) schools in Altındağ, Ankara, who were determined through a random sampling method. The data were collected through Teacher Leadership Scale, Self-Efficacy Scale, and Job Performance Scale. A relational survey model was adopted in the study. The data were analyzed through quantitative analysis techniques, including descriptive statistics, correlation analysis and multiple linear regression analysis. The findings indicated high levels of perceptions of teacher leadership, self-efficacy, and performance in teachers. Moderate, positive, and significant relationships were observed among teacher leadership, teacher self-efficacy and teacher performance. In addition, teacher leadership was shown to predict self-efficacy and performance significantly. The findings pointed out that teacher leadership behaviors were an important concept involved in teacher self-efficacy and performance.

Keywords: Teacher leadership, teacher self-efficacy, teacher performance, school.

ÖZ: Bu araştırmada öğretmen liderliği, öğretmen öz yeterliliği ve öğretmen performansı arasındaki ilişkiler öğretmen görüşlerine göre incelenmiştir. Araştırmaya Ankara ili Altındağ ilçesinde kamu K12 okullarında görev yapan 401 öğretmen katılmıştır. Araştırma verileri Öğretmen Liderliği Ölçeği, Öz yeterlilik Ölçeği ve İş Performansı Ölçeği ile toplanmıştır. Araştırmada ilişkisel tarama modeli benimsenmiştir. Veri kümesi üzerinde nicel analiz teknikleri uygulanmıştır. Araştırma verileri betimsel istatistikler, korelasyon analizi ve çoklu doğrusal regresyon analizi ile çözümlenmiştir. Bulgulara göre öğretmenlerin öğretmen liderliği, öz yeterlilik ve performans algıları yüksek düzeydedir. Öğretmen liderliği, öğretmen öz yeterliği ve öğretmen performans1 arasında orta düzeyde, pozitif ve anlamlı ilişkiler gözlemlenmiştir. Ayrıca öğretmen liderliğinin öz yeterlilik ve performansı anlamlı şekilde yordadığı tespit edilmiştir. Bulgular öğretmen liderliği davranışlarının öğretmen öz yeterlilik ve öğretmen performansı üzerinde rol oynayan önemli bir kavram olduğuna işaret etmiştir.

Anahtar kelimeler: Öğretmen liderliği, öğretmen öz yeterliliği, öğretmen performansı, okul.

\footnotetext{
* Corresponding Author: Asst. Prof. Dr., Süleyman Demirel University, Isparta, Turkey, yenerakman@sdu.edu.tr, https://orcid.org/0000-0002-6107-3911
} 
In the 20th century, school leadership research mostly focused on the behaviors of school administrators that gained power from their legal positions. Today, however, teacher leadership has been the subject of many studies as an important concept (Blackman, 2010; Carver, 2010; Hunzicker, 2012; Jacobson, 2011; Katzenmeyer \& Moller, 2009; Leonard et al., 2012). Specified as a reflection of democratic participation in school, distributed leadership is particularly considered to influence the decisionmaking process. In fact, some researchers stated that distributed leadership was the basis of teacher leadership (Frost, 2008; Gronn, 2000, p. 324; Pounder, 2006). Teachers should be given the opportunity to leave the classroom setting and cooperate with their environment to realize and develop their leadership capacities (Dozier, 2007). Similarly, teacher leadership is an opportunity for teachers to be a part of the decision-making process (Donaldson \& Johnson, 2007). These necessitate a versatile view on administration and the need for the participation of different voices in the administration of today's schools rather than traditional leadership approaches. The participation of stakeholders in administrative processes is considered to contribute to school efficiency. It is also stated that teacher leaders have the willingness, knowledge, and skills to initiate the process of change in schools (DiRanna \& Loucks-Horsley, 2001; Hunzicker, 2012).

It is well-established that administrators and colleagues significantly affect teachers' leadership behaviors. The positive climate in schools might encourage teacher leader candidates to participate in administrative processes. In this process, the support, guidance, and trust provided especially by school administrators can increase teachers' willingness to take responsibility. School administrators play an important role in the development of teacher leadership (Buckner \& McDowelle, 2000). For instance, Diamond and Spillane (2016) stated that teacher leadership largely depends on the leadership approaches of administrators. Teacher leader candidates are appreciated for their innovative practices, support for their colleagues, sensitivity to school problems and efforts to be a part of the solution. Thus, teachers' courage and multifaceted responsibility skills might improve. This is considered to increase the self-efficacy and self-confidence of teacher leader candidates and encourage their performance behaviors in time. As a psychological construct, self-efficacy is believed to be affected particularly by school administrators' approach to leadership, teachers' level of participation in decisions, and interpersonal cooperation (Guo et al., 2011; Shachar \& Shmuelevitz, 1997; Skaalvik \& Skaalvik, 2007).

Additionally, the positive interaction between school administrators and teachers was observed to facilitate the emergence of leadership behaviors of teachers by increasing teacher motivation (Lieberman \& Friedrich, 2010). Similarly, teacher motivation plays an important role in leadership skills (Reeves \& Lowenhaupt, 2016). These indicate the importance of motivation on teachers' self-efficacy beliefs and leadership behaviors. Performance is another construct positively related to motivation. Research has shown that employees with higher motivation also have higher performances (Akman, 2018; Woessmann, 2011). Self-efficacy, in particular, can be regarded as one of the antecedents of teacher leadership. Teacher leaders affect and direct their environment in many ways and enable new practices to become widespread throughout the school. It is also acknowledged that teachers who are monitored and 
have an impact on their environment have high educational performances (Hunzicker, 2012).

In this study, the development of teacher leadership is considered to contribute to the educational processes in schools. Also, teacher leadership points to a partially informal process facilitating a more friendly work environment with other teachers. In this environment, it can be asserted that leader teachers who guide and train their colleagues with expert knowledge might support their development. Therefore, this might direct teacher development in schools to an alternative other than just individual efforts or formal in-service training processes cooperated between colleagues. It is established that teachers who feel their instructional qualifications enhance during the informal education process have strengthened self-confidence and self-efficacy. Additionally, teachers who have mastered their fields in terms of expertise and pedagogy are predicted to improve in terms of effectiveness and performance and considered to raise the students' academic success. In the literature, it has been observed that high teacher self-efficacy increases teacher performance and student academic success (Olsen, 2008; Wahlstrom \& Louis, 2008). In addition, the adoption of the teacher leadership approach in schools suggests that the workload of school administrators might reduce. For example, school administrators can solve problems informally through teacher leaders instead of directly intervening in some problems among teachers. This can therefore be time-saving for school administrators.

Moreover, teacher leadership is an approach that affects not only teachers but also all employees developmentally. It turns stagnation into a dynamic process. As a result, it is an approach that encourages the cooperation and competence of all employees. Teachers can be regarded as role models for students. For this reason, the approach should become widespread so that it affects both employees and students. Recent years have witnessed a growing interest in teacher leadership reflecting the democratic participation in school administration in Turkey. Determining the perceptions about teachers' potential leadership development is therefore deemed significant.

\section{Teacher Leadership}

Despite different conceptualizations, teacher leadership is an approach based on developing other teachers' educational practices by influencing them (Katzenmeyer \& Moller, 2009). Different perspectives have enabled teacher leadership to be examined extensively and considered as an umbrella term. In the literature, teacher leaders are expressed with various titles such as coach, coordinator, and headteacher (Neumerski, 2012). In this process, the teacher leadership initiative tried to determine the basic competences for teacher leadership. Over time, different standards have been developed for teacher leadership. In addition, various certificate and diploma programs have become widespread. It has even been considered a criterion in teacher evaluations in some states in the USA (Colorado Department of Education, 2015; Danielson, 2014).

Moreover, some events on teacher leadership were organized. For instance, "The National Teacher Leadership Initiative" was launched by the National Education Association, wherein the competences of teacher leaders were discussed. Furthermore, the Center for American Progress held an event titled "Teacher Leadership" (Wenner \& Campbell, 2017). Crippen and Willows (2019) defined teacher leaders as individuals 
who inspire, encourage, and empower their colleagues. It was emphasized that distributed and collaborative leadership approaches were at the core of teacher leadership (Frost, 2008; Gronn, 2000, p. 324; Pounder, 2006). Teacher leadership is therefore expressed as a more dynamic and spontaneous phenomenon rather than static by structure. In other words, it can be asserted that the construct develops in an informal context. This can also facilitate the emergence of potential leaders among teachers. Also, teacher leadership develops continuously and has an informal leadership role (Frost, 2008; Pounder, 2006). York-Barr and Duke (2004) specified that teacher leadership is a different form of leadership that focuses on cooperation rather than authority. Similarly, teacher leadership is associated with the democratization of schools, teacher learning and the culture of cooperation in schools (Muijs \& Harris, 2003). It can further be emphasized that teacher leaders exhibit transformational leadership qualities and direct other teachers to various activities that might ensure the development of schools (Pounder, 2006).

It is acknowledged that teacher leaders affect other teachers by sharing innovative learning experiences, providing community service, mentoring, participating in workshops, contributing to the solution of in-school or environmental problems, and connecting with universities (Crippen \& Willows, 2019; Petrie, 1995; Reeves \& Lowenhaupt, 2016). These practices can be considered teachers' getting out of the classroom and expanding their area of influence. According to Danielson (2006), the capacity of teachers to influence, direct and motivate their colleagues and other employees lie at the center of teacher leadership. Therefore, teacher leadership was expressed as an instrument enhancing teacher professionalism and student achievement indirectly (Crowther et al., 2009; Leithwood et al., 2010). As the official leaders of their schools, school administrators play a critical role in the development of teacher leaders. School administrators with an approach and a visionary perspective deprioritizing the hierarchical status relations might try to achieve the school's objectives in a collective understanding with teachers (Andrews \& Lewis, 2007). Besides, Lieberman and Friedrich (2010) declared that teachers might have higher motivation and exhibit active leadership behavior when they express their views freely and administrators endorse their views. In addition, teachers' self-confidence increases when school principals share their experiences with teachers, showing that they trust, support, and encourage teachers (Buckner \& McDowelle, 2000).

Katzenmeyer and Moller (2009) suggested that teacher leaders exhibit leadership behavior in four different areas: (i) school management, (ii) student activities, (iii) official tasks, and (iv) teacher leadership. Some researchers examined the construct in a three-dimensional structure in cooperation with organization, profession, and colleagues (Beycioğlu \& Aslan, 2010; York-Barr \& Duke, 2004). Teacher leadership consists of four dimensions: (i) the source of legitimacy of leadership, (ii) support to do the job, (ii) the purpose of the teacher influence, and (iv) the method of influence (Berg \& Zoellick, 2018). Addressing teacher leadership with different perspectives in the literature makes it difficult to define and determine which dimensions it comprises. This demonstrated the need for leader behavior in practice and changes in the process of being a leader. Some researchers have accordingly discussed teacher leadership in the context of the individual's practical behavior and identity acquisition process. The practical process concentrates on teacher activities, such as creating a culture of success, enhancing the 
learning environment, and encountering barriers to the school structure (Crowther et al., 2009; York-Barr \& Duke, 2004). On the other hand, identity acquisition indicates the experiences in the leadership process, such as personal experiences, development of trust, social roles, and interactions (Gonzales \& Lambert, 2001). The approach in this study mostly focuses on the practical behaviors of teachers within the context of teacher leadership dimensions.

Teacher leadership was extensively discussed in previous studies. Prevalent discussion points were the effects of teachers' classroom practices, experiences, motivations, professional development programs, teacher quality, or burnout on leadership skills (Cheng \& Szeto, 2016; Reeves \& Lowenhaupt, 2016; Snoek \& Volman, 2014). It can be asserted that the studies examining teacher leadership in Turkey have also increased. In these studies, data collection tools were developed to measure the perception of the construct (Beycioğlu \& Aslan, 2010). The studies also sought to determine the opinions of teachers about the construct (Beycioğlu \& Aslan, 2012; Kılınç \& Recepoğlu, 2013) and its relationship with different types of organizational behaviors such as motivational language (Demir, 2014), leader-member exchange (Öztürk \& Şahin, 2017), classroom management tendencies (Öntaş \& Okut, 2017) and school effectiveness (Cansoy \& Parlar, 2018).

\section{Teacher Self-Efficacy}

Teachers are one of the most critical elements behind student achievement. Despite the significance of teachers' professional and cultural competences and expertise to cultivate qualified students, their psychological status might also influence educational efficiency. Self-efficacy can be defined as a construct involved in the psychology of teachers in the school environment. Studies have shown that self-efficacy is a contemporary construct despite being examined for the last few decades (Bandura, 1977, 1997; Cheung, 2008; Hipp \& Bredeson, 1995; Kaçar \& Beycioğlu, 2017; Skaalvik \& Skaalvik, 2007; Tschannen-Moran \& Johnson, 2011). The basis of the selfefficacy construct comes from the Social Cognitive Theory put forward by Bandura (1977). Self-efficacy is defined as an individual's belief in their abilities in the process of successfully performing an action (Bandura, 1977). Tschannen-Moran et al. (1998) asserted that self-efficacy is the belief in teachers' ability to organize and perform the assigned practices to complete a teaching task in school. In other words, the selfefficacy perceptions of teachers might imply teachers' relationship with various factors such as teaching strategy, methods and techniques, approach to environmental organization, classroom management skills and interaction with students.

Research pointed out that teacher self-efficacy is related to individual differences and school characteristics (Hoy \& Woolfolk, 1993). Factors such as school climate, leadership styles of school administrators, the decision-making structure of schools, teachers' professional experiences, and teacher collaboration were related to teacher self-efficacy (Guo et al., 2011; Hipp \& Bredeson, 1995). Studies in the literature found that professional experience positively affects self-efficacy (Cheung, 2008; Wolters \& Daugherty, 2007). In addition, it was observed that the strong interaction between the internal stakeholders of schools and the influence of teachers on various decisions enhanced the self-efficacy of teachers (Moore \& Esselman, 1992; Shachar \& Shmuelevitz, 1997). Since schools are socially dominant institutions, 
interpersonal relations can affect their functioning. In this sense, a sincere working environment is considered to provide a supportive school climate, wherein teachers might increase their multifaceted competences with a mutual understanding. Similarly, it was reported that school administrators who supported teachers contributed to their self-efficacy by establishing trust- and respect-based relationships (Skaalvik \& Skaalvik, 2007).

Bandura (1997) asserted that vicarious experience, verbal persuasion, psychological arousal, and mastery experience affected teachers' self-efficacy beliefs. Vicarious experience is the observation of positive or negative experiences by following the lesson taught by an expert teacher. Verbal persuasion is the verbal interactions about teacher's performance or success. Psychological arousal is the sense of efficacy, either of anxiety or excitement, gained as a result of an activity. Mastery experience is the experiences gained in the process of a course taught by the teacher (Tschannen-Moran et al., 1998). Previous research showed that the perceptions of teacher candidates about their talents are influenced by the quality of supervision (verbal persuasion) and experiences of teaching skill (mastery experience) (Yeung \& Watkins, 2000). It was also emphasized that the verbal persuasion attempts (inter-individual relationship) of administrators and colleagues contributed significantly to the self-efficacy beliefs of young teachers (Tschannen-Moran \& Johnson, 2011). In fact, research showed that in the beginning years of teaching, self-efficacy beliefs changed frequently, and positive interpersonal interactions enhanced the self-efficacy of young teachers (Bandura, 1997). In line with these findings, positive interactions with administrators and colleagues in the school environment might be claimed to enable teachers to express themselves more comfortably. Teachers can thus become a guide in their environment by discovering and revealing their hidden powers. Considering the relationship between interpersonal relations, teacher leadership and self-efficacy at school, addressing the related constructs together is deemed important.

\section{Teacher Performance}

The existence of organizations depends on their ability to achieve their goals through effective and efficient practices. Quality education can be achieved through the interaction and harmony of numerous elements, including teacher performance. Performance is expressed as the behavior of an employee to achieve a specific goal (Campbell et al., 1990). According to Özdemir (2014), teacher performance is the behaviors that teachers exhibit by integrating their knowledge, skills, and motivation to achieve organizational goals. Performance is an organizational behavior influenced by various factors that can be individual (e.g., experience, knowledge, skill, age, etc.) or environmental (e.g., administrative approach, organizational climate, colleagues, characteristics of job, etc.). High performance is rooted in the harmonious relationship between the mentioned factors (Weightman, 2004, p. 160-161). In the literature, Cerit (2012) stated that performance is related to leader-member interaction, while Pitts (2009) pointed out that qualified internal communication increases performance. Also, some researchers have emphasized that performance is positively affected in organizations with clear goals, duties, authorities, and responsibilities (Babin \& Boles, 1996). In addition, Akman (2018) stated that the motivation and performance of teachers increase in schools with high organizational justice. 
Moreover, significant relationships between job satisfaction and performance were found in a meta-analysis study including 312 studies (Judge et al., 2001). Furthermore, Dilbaz-Sayin and Arslan (2018) noted that professional development, organization of the learning environment, interaction in the classroom, contribution to the development of students, interaction with the environment and being a role model are the factors to be observed in evaluating teacher performance. When the factors affecting performance are considered holistically, it is safe to say that performance is affected by personal and environmental factors, whether in schools or different sectors. The approach of self-efficacy and teacher leadership in the present study can also be considered in the context of both individual and environmental factors.

Studies indicated that teacher performance was associated with school administrators' leadership approaches and leadership adjustment (Abu Nasra \& Arar, 2019; Cerit, 2012; Cheng, 2013; Korkmaz, 2005; Özdemir \& Gören, 2017; Tuytens \& Devos, 2012). While examining the construct, most researchers based performance on transformational leadership theory (Bass, 1985), leader-member exchange theory (Graen, 1976) and social change theory (Blau, 1964). These theories propose that performance might improve in a leader-employee relationship with a just social sharing. According to two factor theory, the performance of employees is affected by meeting their psychological needs such as autonomy, empowerment, and personal development (Herzberg et al., 1959). In the process of teacher empowerment, teachers' perceptions of self-efficacy and their levels of participation in decisions play an important role (Bogler $\&$ Nir, 2012). These explanations show that the presence of teachers in an environment enabling them to take the initiative while performing their duties positively affects various behavioral outcomes. It also points out the importance of the school administrators creating a supportive environment.

\section{The Relationship among Teacher Leadership, Teacher Self-Efficacy and Teacher Performance}

Teacher leaders can be regarded as informal leaders in schools. It can be maintained that leader teachers affect other teachers just as school administrators affect teachers. It is acknowledged that increasing the instructional competence of their colleagues is among the missions of teacher leaders. Teachers who are instructionally well-endowed are considered to have increased self-confidence. Various studies on this subject have shown that teacher self-efficacy is associated with teaching quality (Guo et al., 2012; Klassen \& Tze, 2014). For instance, Allinder (1994) stated that teachers with a strong sense of self-efficacy are more open to new ideas and more willing to apply new methods to meet students' needs. In addition, Day et al. (2016) noted that the instructional leadership or transformational leadership displayed by school administrators alone is insufficient to explain teacher self-efficacy. Furthermore, it was emphasized that teacher leadership might raise teacher self-efficacy by improving other teachers, school and instructional management.

Various studies regarded teacher self-efficacy as a variable that positively affects teachers' performance (Caprara et al., 2006; Skaalvik \& Skaalvik, 2010; Tims et al., 2012). To exemplify, Saks (1995) pointed out that self-efficacy is the primary determinant of performance. The reason for the increase in performance may be the willingness of teachers who feel competent in any subject to exert sufficient effort 
concerning their duties. Additionally, teachers with strong self-efficacy were claimed to work harder, especially in difficult times (Tschannen-Moran \& Hoy, 2001). Therefore, it can be seen that the high self-efficacy of teachers also increases their performance (Elliott et al., 2010; Olsen, 2008; Schunk \& Ertmer, 1999). The mentioned arguments indicate direct relationships among the variables.

Most studies have shown that quality leadership positively impacts employee performance (Abu Nasra \& Heilbrunn, 2015; Chen \& Kanfer, 2006). Transformational leadership significantly affects performance in studies on leadership and performance (Fernet et al., 2015; Vigoda-Gadot, 2007). Considering that teacher leaders exhibit transformational leadership qualities (Pounder, 2006), significant relationships between performance and teacher leadership might be predicted. Namely, both types of leadership indicate active practices and emotional interactions (Bass, 1985). It can be argued that the innovative educational approaches expected from teacher leaders, proactive behaviors towards the solution of problems, and sincere cooperation between individuals support these views. This also indicates that teacher leaders take more responsibility in in-school practices. In this sense, it was emphasized that teachers who have quality interactions with school administrators voluntarily perform higher responsibilities (Moss et al., 2009). Also, school administrators' approach to leadership and cooperative behaviors with teachers was positively associated with teacher selfefficacy (Guo et al., 2011).

\section{Purpose}

This study aimed to reveal the relationships among teacher leadership, teacher self-efficacy, and teacher performance. In this regard, the following research questions were addressed:

1. What is the level of teachers' perceptions of teacher leadership, self-efficacy and performance?

2. Are there statistically significant relationships among teacher leadership, selfefficacy, and performance?

3. Is organizational development (OD) a significant predictor of self-efficacy and performance?

4. Is professional development (PD) a significant predictor of self-efficacy and performance?

5. Is collaboration with colleagues $(\mathrm{CwC})$ a significant predictor of self-efficacy and performance?

\section{Method}

This study focused on the relationships among teacher leadership, teacher selfefficacy, and teacher performance. Data were analyzed by quantitative methods in this study, adopting a relational survey model.

\section{Sample}

The study was carried out in state (K12) schools in Altındağ, Ankara. According to the data from Ankara Provincial Directorate of National Education [APDNE], 4689 teachers work in these institutions (APDNE, 2020). The research was conducted with the sample selected from the population formed by teachers. While determining the 
number of teachers to be included in the sample, a table of sample size was used. Reaching at least 333-357 teachers with 5\% tolerance was deemed sufficient for the representation of the population (Cohen et al., 2007, p. 104). The participants were determined by convenient sampling. In this regard, considering the possibility of data loss, 500 teachers were aimed to reach, but the feedback was received from 401 teachers. 199 of the participants in the sample were women (49.6\%) and 202 were men $(50.4 \%)$. In addition, 108 of them work in primary school (26.9\%), 186 in secondary school (46.4\%) and 107 in high school (26.7\%).

\section{Data Collection Tools}

In this study, teachers' perceptions of teacher leadership were determined through "Teacher Leadership Scale" developed by Beycioğlu and Aslan (2010). Perceptions of self-efficacy were ascertained through "Teacher Self-efficacy Scale" adapted to Turkish by Karaoğlu (2019). Perceptions of performance were identified through "Job Performance Scale" adapted by Çöl (2008).

\section{Teacher Leadership Scale (TLS)}

Teachers' perceptions of teacher leadership were measured by TLS, made up of 25 items and a three-factor structure (OD, $\mathrm{PD}$ and $\mathrm{CwC})$. The scale was developed in a five-point Likert style. With the exploratory factor analysis (EFA), all dimensions of the scale whose structure validity was tested explained $57.23 \%$ of the total variance. In addition, the Cronbach's Alpha coefficient indicated the reliability of the scale (OD: .87; PD: .87; CwC: .92). Some of the sample items in the scale were as follows: "Willingness to collect information and prepare reports about the school" and "Giving confidence to students". Analyses were repeated on the current dataset. As a result of the CFA, the $t$ values of items 5, 4, and 6 were found to be insignificant. These items were therefore excluded from the dataset. Moreover, a correlation was established between items 24-25 in line with the modification indices. Goodness of fit values achieved as a result of the final CFA indicated the validity of the scale at an acceptable level $\left[\chi^{2}=754.04 ; d f=169 ; \chi 2 / d f=4.46 ; \mathrm{AGFI}=.80 ; \mathrm{RMSEA}=.08 ; \mathrm{CFI}=.93 ; \mathrm{NFI}=.90\right]$. Cronbach's alpha reliability coefficients were calculated .65 for OD, .84 for PD, .70 for CWC with an overall value of .92. Given the analyses, the TLS was proved to be a valid and reliable data collection instrument.

\section{Teacher Self-Efficacy Scale (TSES)}

TSES consists of 12 items under three dimensions (i.e., student engagement, teaching strategies and classroom management). As a result of the CFA analysis of the original scale, the goodness of fit values was calculated as: $\chi 2=326.69 ; d f=50$;

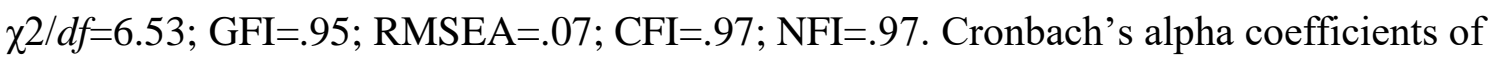
the scale showed that the scale was a reliable data collection instrument (student engagement: .73, teaching strategies: .75, classroom management: .74, and overall: .88). The scale has such items as: "How much can you try to control behavior that disrupts the order of the class?" and "How much effort can you make to ensure that your students comply with classroom rules?" Validity and reliability analyses of the scale were repeated. Since the $t$ value of item 1 was not significant ( $t: 1.74)$ according to the CFA, it was removed from the dataset, and the analysis was repeated. Modification 
suggestions were applied in order not to reduce the content validity in the second CFA. As a result of the second CFA, a correlation was established between error items 11-12 and error items 6-5, considering the modification indices. Following this analysis, the goodness of fit indices was: $\chi 2=167.88 ; d f=42 ; \chi 2 / d f=3.99 ; \mathrm{AGFI}=.89$; RMSEA=.08; $\mathrm{CFI}=.94 ; \mathrm{NFI}=.92$. In the analysis, $\chi 2 / d f$ value was found above the specified range. More than one fit indices were found as a result of the CFA. In this process, all indices were evaluated together instead of a single indice while determining the fit (Jöreskog \& Sörbom, 1993). Reliability analysis indicated the reliability of the scale (student engagement: .70, teaching strategies: .69, classroom management: .82 and overall: .84). Validity and reliability analyses showed that TSES was a valid scale.

\section{Job Performance Scale (JPS)}

The scale consists of four items. The Cronbach alpha reliability coefficient of the JPS was calculated as .82. Validity and reliability analyses were also repeated on the existing dataset. Since the $t$ value of item 1 was insignificant ( $t$ : .46) as a result of the CFA, the analysis was repeated by removing it from the dataset. Perfect goodness of fit indices were achieved after the second CFA $(\chi 2=.0 ; d f=0 ; \mathrm{AGFI}=1.0 ; \mathrm{RMSEA}=.00$; $\mathrm{CFI}=1.0 ; \mathrm{NFI}=1.0$ ). In addition, the reliability coefficient of the scale was found to be .70. As a result, it was established that the JPS is a data collection instrument that can be used in the current study.

\section{The Procedures and Data Analysis}

The data were collected in June-July, 2020 by reaching teachers through a form prepared on Google forms. In the study, the perception level of the variables was analyzed through descriptive statistics (arithmetic mean, standard deviation, etc.). The level of the relationships among the variables was performed by correlation analysis. Predictive relations were revealed through regression analysis. The data were first transferred to the SPSS analysis program. It was then investigated whether the dataset met the assumptions for multivariate analysis. These assumptions can be expressed as normal distribution of data, multicollinearity, and lack of autocorrelation among the variables. For normality assumption, kurtosis and skewness values were examined. Values between -1.35 and 1.17 for teacher leadership, -1.43 and 1.38 for self-efficacy, and -.89 and -.02 for performance were calculated. Values between \pm 1.5 indicate univariate normality. Homoscedasticity was examined for the assumption of multivariate normality. The presence of homoscedasticity indicates the assumption of normality. In this context, the scatter plot showing the spread as the same width towards the middle indicates the homoscedasticity (Tabachnick \& Fidell, 2013). Multicollinearity was tested through VIF and tolerance values. In the study, VIF and tolerance values were calculated between 2.49 and .40 for OD, 2.89 and .34 for PD and 2.56 and .39 for $\mathrm{CwC}$. In the literature, the VIF value less than 10 and the tolerance value higher than .2 are interpreted as no multicollinearity (Çokluk et al., 2016, p. 38; Field, 2005; Kalayc1, 2014, p. 267-268). The presence of autocorrelation was also examined with Durbin Watson (DW) value. Kalaycı (2014, p. 268) pointed out that the DW value between 1.5 and 2.5 indicates no autocorrelation. In the current study, the DW value was 1.72 for student engagement, 1.87 for teaching strategies, 1.76 for classroom management, and 2.01 for performance. The findings showed that all the assumptions were satisfactory. When evaluating the CFA results, special attention was 
paid so that $\chi 2 / \mathrm{df}$ rate was less than 5 , and RMSEA was less than .08 while CFI and NFI values were higher than .90 (Çokluk et al., 2016, p. 271-272). Intervals were considered in the interpretation of arithmetic means. The range for the scales was identified as "very low" for 1.00 and 1.79 , "low" for 1.80 and 2.59 , "medium" for 2.60 and 3.39, "high" for 4.40 and 4.19 and "very high" for 4.20 and 5.00. In evaluating the relationships among the variables, the range of 0.0-.30 was considered "low", .31-.70 "medium" and .71-1.0 "high" (Büyüköztürk et al., 2012, p. 92).

\section{Ethical Statement}

This study was conducted with the permission of Social and Human Sciences Ethics Committee of SDU dated 09/06/2020 issued 91/4.

\section{Findings}

The results about teacher leadership, teacher self-efficacy, teacher performance and arithmetic mean and standard deviation for all dimensions were presented in Table 1 .

Table 1

Arithmetic Means and Standard Deviations

\begin{tabular}{|c|c|c|c|c|}
\hline Scale & & Factors & $\bar{X}$ & Ss \\
\hline \multirow{3}{*}{ TLS } & \multirow{3}{*}{$\bar{X}=3.93$} & 1. OD & 3.89 & .64 \\
\hline & & 2. PD & 4.02 & .77 \\
\hline & & 3. $\mathrm{CwC}$ & 3.88 & .77 \\
\hline \multirow{3}{*}{\multicolumn{2}{|c|}{ TSES $\quad \bar{X}=3.92$}} & 4. $\mathrm{SE}$ & 3.76 & .86 \\
\hline & & 5. TS & 4.02 & .81 \\
\hline & & 6. $\mathrm{CM}$ & 3.98 & .86 \\
\hline JPS & & 7. Perf & 4.05 & .79 \\
\hline
\end{tabular}

$N=401$ (OD: Organizational development; PD: Professional development; $\mathrm{CwC}$ : Cooperation with colleagues; SE: Student engagement; TS: Teaching strategies; CM: Classroom management; Perf: Performance)

As Table 1 shows, teacher leadership, teacher self-efficacy and teacher performance were at a "high" level. Furthermore, a high level of perception was observed in all factors. The results of correlation analysis about teacher leadership, teacher self-efficacy and teacher performance were presented in Table 2. 
Table 2

Correlations between Variables

\begin{tabular}{|c|c|c|c|c|c|c|c|}
\hline Factors & 1 & 2 & 3 & 4 & 5 & 6 & 7 \\
\hline 1. OD & - & & & & & & \\
\hline 2. PD & $.74 * *$ & - & & & & & \\
\hline 3. $\mathrm{CwC}$ & $.70 * *$ & $.75^{* *}$ & - & & & & \\
\hline 4. SE & $.40 * *$ & $.40 * *$ & $.46^{* *}$ & - & & & \\
\hline 5.TS & $.52 * *$ & $.62 * *$ & $.52 * *$ & $.47 * *$ & - & & \\
\hline 6.CM & $.48^{* *}$ & $.62 * *$ & $.52 * *$ & $.36^{* *}$ & $.56^{* *}$ & - & \\
\hline 7.Perf & $.61 * *$ & $.64 * *$ & $.57 * *$ & $.52 * *$ & $.61 * *$ & $.55^{* *}$ & - \\
\hline
\end{tabular}

**p<.01; $N=401$ (OD: Organizational development; PD: Professional development; CwC: Cooperation with colleagues; SE: Student engagement; TS: Teaching strategies; CM: Classroom management; Perf: Performance)

As Table 2 shows, correlation coefficients of OD with SE $(r=.40 ; p<.01)$, TS $(r=.52 ; p<.01), \mathrm{CM}(r=.48 ; p<.01)$ and perf $(r=.61 ; p<.01)$; PD with SE $(r=.40 ; p<.01)$, $\mathrm{TS}(r=.62 ; p<.01), \mathrm{CM}(r=.62 ; p<.01)$ and perf $(r=.64 ; p<.01) ; \mathrm{CwC}$ with SE $(r=.46$; $p<.01)$, TS $(r=.52 ; p<.01), \mathrm{CM}(r=.52 ; p<.01)$ and perf $(r=.57 ; p<.01)$ indicated positive significant correlations among all factors at a moderate level. Multiple linear regression analysis results showed the predictability of all dimensions of teacher leadership on selfefficacy and performance as presented in Table 3.

Table 3

Multiple Linear Regression Analysis Results

\begin{tabular}{|c|c|c|c|c|c|c|c|c|c|c|c|c|}
\hline & \multicolumn{3}{|c|}{ Student Engagement } & \multicolumn{3}{|c|}{ Teaching Strategies } & \multicolumn{3}{|c|}{$\begin{array}{c}\text { Classroom } \\
\text { Management }\end{array}$} & \multicolumn{3}{|c|}{ Performance } \\
\hline & $B$ & $t$ & $R^{2}$ & $B$ & $t$ & $R^{2}$ & $B$ & $T$ & $R^{2}$ & $B$ & $t$ & $R^{2}$ \\
\hline & & & .22 & & & 40 & & & 40 & & & 46 \\
\hline OD & .169 & 1.806 & & .116 & 1.496 & & .006 & .069 & & .327 & $4.561 *$ & \\
\hline PD & .093 & 1.103 & & .524 & $7.524 *$ & & .589 & $7.957 *$ & & .357 & $5.528 *$ & \\
\hline $\mathrm{CwC}$ & .346 & $4.380 *$ & & .091 & 1.392 & & .145 & $2.094 *$ & & .132 & $2.186^{*}$ & \\
\hline
\end{tabular}

$N=401 ; * p<.05$.

As Table 3 shows, three dimensions of teacher leadership explained 22\% of the total variance $(F=38.873, p<.05)$ regarding teachers' perceptions of student engagement. Only $\mathrm{CwC}(\beta=.346, p<.05)$ significantly predicted SE. In terms of TS, all dimensions of teacher leadership together explained $40 \%$ of the total variance $(F=89.774, p<.05)$. It was found that only $\mathrm{PD}(\beta=.524, p<.05)$ was a significant predictor of TS. Considering teachers' perceptions of $\mathrm{CM}$, all dimensions of teacher leadership together explained $40 \%$ of the total variance $(F=88.415, p<.05)$. It was also found that $\operatorname{PD}(\beta=.589, p<.05)$ and $\mathrm{CwC}(\beta=.145, p<.05)$ significantly predicted $\mathrm{CM}$. Finally, all dimensions of teacher leadership together explained $46 \%$ of the total variance $(F=112.545, p<.05)$ in terms of 
teachers' perceptions of performance. It was further noted that $\mathrm{OD}(\beta=.327, p<.05)$, PD $(\beta=.357, p<.05)$ and $\mathrm{CwC}(\beta=.132, p<.05)$ significantly predicted performance.

\section{Discussion}

In this study, the relationships among teacher leadership, teacher self-efficacy and teacher performance were examined. The participants were 401 teachers working in Altındağ, Ankara. The findings showed that the perceptions of teacher leadership were high. Various studies supported this finding (Beycioğlu \& Aslan, 2012; Cansoy \& Parlar, 2018; Öntaş \& Okut, 2017). In other words, the perceptions about teacher leadership were found to be positive. Teachers' perceptions of professional development, in particular, were found to be higher in teacher leadership. This can be interpreted as the teachers' willingness to communicate effectively with their colleagues, exhibit behaviors open to learning, follow innovations, and take responsibility for the development of the school. In addition, the perceptions of cooperation with colleagues and organizational development were found to be lower than professional development in the study. This finding was consistent with previous research findings (Kılınç \& Recepoğlu, 2013; Yiğit et al., 2013). It follows that teachers cooperating with colleagues hold themselves responsible for their development, share their own experiences to increase their professional competencies, direct and support them. Teachers' lower perception of organizational development can be regarded as avoiding the process of participating in school administration and official tasks and participating in environmental activities. Participation in the decision-making process within the organization is a factor that enhances the quality of organizational functioning. This process might positively affect the individual's commitment to the organization and the perception of organizational citizenship. It was asserted that decisional participation supports organizational development (Aslan \& Ağıroğlu Bakır, 2015). However, the centralized structure of the education system does not considerably allow the spread of distributed leadership behaviors in school administration. By holding the authorities and responsibilities, the administration might therefore prevent other teachers from reaching collaborative opportunities that might enable them to improve their leadership qualities. This finding was found to be similar to the findings of previous studies (Sawyer, 2005; York-Barr \& Duke, 2004). In addition, teachers' reluctance to take part in official duties and other environmental activities may result from intensive teaching activities. Such similar activities mostly do not yield tangible returns (e.g., certificate of achievement, service score, etc.). They are perceived as a waste of time and might increase teachers' reluctance.

This study found that teachers' perceptions of self-efficacy were high. This finding accords with previous literature (Demir, 2018; Kutluca, 2018). According to these findings, teachers expressed their self-efficacy levels as positive. In other words, teachers believed that they had the skills necessary to achieve a goal. This may indicate teachers' ability to reflect the competences forming the basis of the teaching profession, such as pedagogical-field expertise and general knowledge-ability while performing their duties related to their jobs.

Similarly, teachers exhibited their performances at a high level in the study. This finding was also supported by some studies (Akçekoce \& Bilgin, 2016; Akman, 2018; Bakker \& Bal, 2010; Büyükgöze \& Özdemir, 2017; Limon \& Sezgin-Nartgün, 2020; 
Özdemir \& Gören, 2017; Özdemir \& Yirmibeş, 2016; Özgenel \& Aktaş, 2020; Özgenel et al., 2020). In studies investigating teacher performance in recent years, mostly high perception of performance has drawn attention. Various conditions improved in schools relatively considerably compared to the past might account for this. In other words, the developments enhancing teachers' performance can be a relative increase in the insufficient opportunities for teachers to participate in decisions concerning them (Burton et al., 2008), increasing the school's educational power by completing norm staffing of teachers, facilitation of classroom management thanks to the decrease in student numbers (Akalın, 2015) and a more intense encounter of students with technology-based rich learning experiences (Tosuntaş, 2017).

The relationships among variables were also examined in this study. The findings showed that teacher leadership behaviors had significant positive relationships with student engagement, teaching strategies, classroom management and teacher performance. The fact that teacher leaders were in cooperation with colleagues can be considered as a reflection of leadership. Teacher leaders convey their innovative learning experiences to other teachers by emphasizing cooperation in informal relations (Muijs \& Harris, 2003). This accordingly contributes to teachers' professional development and thus to the development of schools (Pounder, 2006). It also positively affects teachers' classroom management skills and teaching strategies. It was asserted that teacher leadership was expressed as an element that increases teachers' professionalism (Crowther et al., 2009). Similarly, Jackson and Bruegmann (2009) emphasized the importance of collaboration in helping employees deal with uncertainties about educational practices at school and in increasing instructional quality. The changes that leadership creates on the organization and its employees can be examined in many ways. Leadership behaviors can be viewed as an important element behind many positive or negative outputs in the organization. In particular, it is striking that the leadership behaviors of teachers that support the professional learning process significantly affect teaching quality, student learning and institutional development (Hallinger et al., 2017; Zheng et al., 2018).

As one of the dimensions of teacher leadership, organizational development was found to be an important predictor of performance. According to the findings, the quality of teachers' behaviors for the development of the school can be viewed as performance. That is, the behaviors teachers perform voluntarily and in administrative duties might increase teacher visibility in schools. This may indicate task performance. Performance has a multidimensional and complex structure, affected by many individual and environmental factors. In this sense, it may be difficult to know which dimension of organizational development affects performance. The current study examined performance in general. However, the relationship in this study can be handled through contextual performance. According to the literature, contextual performance is voluntary behavior excluded in the job description of employees. It supports the psychological and social environment of the organization (Onay, 2011). Expressions such as voluntariness, effort, optional behaviors and team performance are frequently emphasized to explain contextual performance (Robbins \& Judge, 2012). The mentioned expressions are the administrative support displayed by the teachers and participation in the school's relations with environmental factors, etc., in organizational development associated with such actions. 
Furthermore, it was found that organizational development did not predict student engagement, teaching strategies and classroom management among the variables. This might be due to the fact that organizational development is largely caused by administrative duties and environmental factors that affect the school. That is, the dimensions unpredictive of the organizational development emphasized the educational process in the classroom. It is further linked with such actions as formalinformal empowerment in the school, making efforts for the recognition of the school in the society, and exhibiting voluntariness for the participation of environmental factors in the education process. Moreover, this may imply that teachers mostly direct their energies to classroom activities and are not very interested in administrative routines in school. The reason for this may be the perception of waste of time and lack of motivation for related jobs. To prevent this drawback, teachers' perceptions can be raised by developing practices that might encourage teachers who take responsibility for school business administration and environmental relations by school administrators.

Herzberg et al. (1959) stated that meeting the individual development needs of teachers is related to their performances. In other words, teacher leaders exhibiting behaviors towards the professional development of other teachers might be considered to positively impact their educational efficiency by providing them with new learning experiences. Similarly, leadership behavior improved teacher performance (Abu Nasra \& Heilbrunn, 2015). Transformational leadership was found to have significant effects on teacher performance (Fernet et al., 2015). Pounder (2006) asserted that transformational leadership and teacher leadership had similar behavioral patterns. This can be acknowledged as a finding that supports the predictability of teacher leadership on performance in the current research.

Additionally, it was claimed that teachers' expressing their colleagues' achievements or high performances promoted self-efficacy development (TschannenMoran \& Johnson, 2011). In brief, leader teachers are believed to strengthen teachers' self-efficacy beliefs through verbal persuasion. Considering that self-efficacy is an individual's belief in achieving success, an increase in teachers' educational skills is predicted to support their self-efficacy. In addition, no predictive effect was found, although an indirect interaction was expected between professional development and student engagement in the study. This may be due to factors related to professional development. Professional development means having the power to increase the motivation of teachers, enabling them to discover their potential and having a more participatory attitude within the school. There is an incentive for teachers to be an important part of schools. Also, student engagement mostly emphasizes practices for the positive development of student behavior in the classroom. In other words, it is mainly related to behavior management.

Moreover, it was found that cooperation with colleagues significantly predicted such dimensions of self-efficacy as performance, classroom management and student engagement. The behaviors of teacher leaders to enhance the instructional competence of their colleagues might also be said to affect the instructional quality of teachers positively. Various studies on the importance of collaboration among teachers showed that professional collaboration was a significant predictor of teacher self-efficacy (Duyar et al., 2013; Sehgal et al., 2017). In this regard, Guo et al. (2012) pointed out that the quality of teaching had a positive relationship with teachers' self-efficacy 
perceptions. Supporting these findings, Olsen (2008) also stated that teacher selfefficacy was positively interacted with teacher performance.

Moreover, Sehgal et al.'s study (2017) was considered important in terms of providing a holistic perspective to the current study findings. In this study, the effectiveness of teachers' self-efficacy perceptions could be increased with the cooperation between colleagues and the support of school administrators. It was further found that cooperation with colleagues did not significantly predict teaching strategies. Cooperation with colleagues indicated a positive interaction with other teachers in terms of both educational and instructional processes. In this process, $\mathrm{CwC}$ was emphasized to increase the mutual competence of teachers. Instructional strategies mostly refer to the in-class application process. The lack of predictability among the variables may be due to the more superficial and formal relations between teachers rather than the cooperation of teachers towards the implementation process. In other words, cooperation with colleagues may be realized only through sharing documents (e.g., exam papers, course materials, reports, etc.). In this case, there may not be interactions related to the applied teaching process.

\section{Conclusion and Implications}

In conclusion, the study showed that teacher leadership was an important variable to explain teacher performance. In other words, the development of teacher leadership in schools was highly effective on the development of teachers' performance. Teacher leadership was also found to have partial effects on self-efficacy on the basis of dimensions. To increase the interaction and professional collaboration between teachers, interdisciplinary interaction can be developed through meetings organized by teachers in their areas of expertise during out-of-school times. Moreover, a formal (policy makers) or informal performance system can be created to reveal the leadership characteristics of teachers. With this system, teachers' self-confidence and competence can be enhanced, and the way to contribute to their environment can be paved. This study was carried out in state educational institutions. Therefore, taking the opinions of teachers working in private education institutions can provide a holistic view of leadership, self-efficacy, and performance. In addition, examining the relationship between teacher leadership and different organizational behavior outcomes such as motivation, commitment and burnout can contribute to the literature. As another suggestion, examining how teachers' leadership tendencies are handled in different working groups (school principal, student, etc.) and with various research methods may reveal rich perspectives on the concept.

\section{Limitations}

This study has various limitations. First, the study group was located in Altındağ, Ankara, thus making it difficult to generalize the findings. Second, the teachers' responses to the scales might be socially desirable, therefore weakening their objectivity. This might be because teachers made their own self-evaluations when exhibiting behaviors or attitudes in the scales. Third, more comprehensive findings might be obtained by qualitative or mixed methods instead of quantitative methods. 


\section{References}

Abu Nasra, M., \& Arar, K. (2019). Leadership style and teacher performance: mediating role of occupational perception. International Journal of Educational Management, 34(1), 186-202. https://doi.org/10.1108/IJEM-04-2019-0146

Abu Nasra, M., \& Heilbrunn, S. (2015). Transformational leadership and organizational citizenship behavior in the Arab educational system in Israel: the impact of trust and job satisfaction. Educational Management Administration \& Leadership, 44(3), 80-396. https://doi.org/10.1177/1741143214549975

Akalın, S. (2015). Opinions and needs of mainstream classroom teachers about classroom management. Ankara Üniversitesi Ĕ̆itim Bilimleri Fakültesi Özel Ĕgitim Dergisi, 16(3), 215-234

Akçekoce, A., \& Bilgin, K. U. (2016). Okul müdürlerinin liderlik stilleri ve öğretmen performansı. Çağdaş Yönetim Bilimleri Dergisi, 2(2), 1-23.

Akman, Y. (2018). The investigation of the relationships between organisational justice, work motivation and teacher performance. Çukurova University Faculty of Education Journal, 47(1), 164-187. https://doi.org/10.14812/cuefd.371642

Allinder, R. M. (1994). The relationship between efficacy and the instructional practices of special education teachers and consultants. Teacher Education and Special Education, 17, 86-95.

Andrews, D., \& Lewis, M. (2007). Transforming practice from within: The power of the Professional learning community. In L. Stoll \& K. Seashore Louis (Eds.), Professional learning communities: Divergence, depth and dilemmas (pp. 132147). Open University Press.

Ankara İl Mili Eğitim Müdürlüğü (AİMEM) (2020, April 21). Eğitim istatistikleri. Retrieved from http://ankara.meb.gov.tr/www/egitim-istatistikleri/icerik/24.

Aslan, M., \& Ağıroğlu Bakır, A. (2015). The interaction of distributed leadership and organizational commitment in schools: a qualitative study. Electronic International Journal of Education, Arts, and Science, 1(2), 1-30.

Babin, B. J., \& Boles, J. S. (1996). The effects of perceived co-worker involvement and supervisor support on service provider role stress, performance and job satisfaction. Journal of Retailing, 72(1), 57-75.

Bakker, A. B., \& Bal, P. M. (2010). Weekly work engagement and performance: A study among starting teachers. Journal of Occupational and Organizational Psychology, 83, 189-206. https://doi.org/10.1348/096317909X402596

Bandura, A. (1977). Self-efficacy: toward a unifying theory of behavioral change. Psychological Review, 84, 191-215. https://doi.org/10.1037/0033-295X.84.2.191

Bandura, A. (1997). Self-efficacy: The exercise of control. W. H. Freeman \& Co.

Bass, B. (1985). Leadership and performance beyond expectations. Free Press.

Berg, J., \& Zoellick, B. (2018). Teacher leadership: toward a new conceptual framework. Journal of Professional Capital and Community, 4(1), 2-14. https://doi.org/10.1108/JPCC-06-2018-0017

Beycioğlu, K., \& Aslan, B. (2010). Teacher leadership scale: A validity and reliability study. Elementary Education Online, 9(2), 764-775. 
Beycioğlu, K., \& Aslan, B. (2012). Teachers and administrators' views on teacher leadership: a mixed methods study. Educational Administration: Theory and Practice, 18(2), 191-223.

Blackman, A. (2010). Coaching as a leadership development tool for teachers. Professional Development in Education, 36(3), 421-441.

Blau, P. (1964). Exchange and power in social life. John Wiley.

Bogler, R., \& Nir, A. (2012). The importance of teachers' perceived organizational support to job satisfaction: what's empowerment got to do with it?. Journal of Educational Administration, 50(3), 287-306. https://doi.org/10.1108/09578231211223310

Buckner, K. G., \& McDowelle, J. O. (2000). Opportunities, and support developing teacher leaders: Providing encouragement. NASSP Bulletin, 84, 35-41.

Burton, J. P., Sablynski, C. J., \& Sekiguchi, T. (2008). Linking justice, performance, and citizenship via leader-member exchange. Journal of Business Psychology, 23, 51-61. https://doi.org/10.1007/s10869-008-9075-z

Büyükgöze, H., \& Özdemir, M. (2017). Examining job satisfaction and teacher performance within Affective Events Theory. Inonu University Journal of the Faculty of Education, 18(1), 311-325. https://doi.org/10.17679/inuefd.307041

Büyüköztürk, Ş., Çokluk, Ö., \& Köklü, N. (2012). Sosyal Bilimler için istatistik. Pegem A Yayıncilik.

Campbell, J. P., McHenry, J. J., \& Wise, L. L. (1990). Modeling job performance in a population of jobs. Personnel Psychology, 43, 313-333.

Cansoy, R., \& Parlar, H. (2018). Teacher leadership as a predictor of school effectiveness. Kastamonu Education Journal, 26(3), 925-934.

Caprara, G. V., Barbaranelli, C., Steca, P., \& Malone, P. S. (2006). Teachers' selfefficacy beliefs as determinants of job satisfaction and students' academic achievement: A study at the school level. Journal of School Psychology, 44(6), 473-490. https://doi.org/10.1016/j.jsp.2006.09.001

Carver, C. L. (2010). Mentors coaching principals in instructional leadership: The case of Rebecca and Ramon. Journal of Cases in Educational Leadership, 13(2), 39-46. https://doi.org/10.1177/1555458910372653

Cerit, Y. (2012). The relationship between leader-member exchange and classroom teachers' performance. Ballkesir University Journal of Social Sciences Institute, 15(28), 33-46.

Chen, G., \& Kanfer, R. (2006). Toward a systems theory of motivated behavior in work teams. Research in Organizational Behavior, 27, 223-267. https://doi.org/10.1016/S0191-3085(06)27006-0

Cheng, A. Y. N., \& Szeto, E. (2016). Teacher leadership development and principal facilitation: Novice teachers' perspectives. Teaching and Teacher Education, 58, 140-148. https://doi.org/10.1016/j.tate.2016.05.003

Cheng, J. (2013). The effect of kindergarten principals' leadership behaviors on teacher work performance. Social Behavior and Personality, 41(2), 251-262. https://doi.org/10.2224/sbp.2013.41.2.251 
Cheung, H. Y. (2008). Teacher efficacy: a comparative study of Hong Kong and Shanghai primary in-service teachers. The Australian Educational Researcher, 35, 103-123.

Cohen, L., Manion, L., \& Morrison, K. (2007). Research methods in education (6th edition). Routledge.

Çokluk, Ö., Şekercioğlu, G., \& Büyüköztürk, Ş. (2016). Sosyal bilimler için çok değişkenli istatistik SPSS ve LISREL uygulamaları. Pegem Akademi,

Çöl, G. (2008). The effects of perceived empowerment on employee performance. Doğuş University Journal, 9(1), 35-46.

Colorado Department of Education. (2015). 2015-16 rubric for evaluating Colorado teachers. $\quad$ Retrieved from https://www.d11.org/cms/lib/CO02201641/Centricity/Domain/526/2015_16\%20ssp psychologistrubric.pdf

Crippen, C., \& Willows, J. (2019). Connecting teacher leadership and servant leadership: a synergistic partnership. Journal of Leadership Education, 18(2), 171180. https://doi.org/10.12806/V18/I2/T4

Crowther, F., Ferguson, M., \& Hann, L. (2009). Developing teacher leaders: How teacher leadership enhances school success. Corwin Press.

Danielson, C. (2006). Teacher leadership that strengthens professional practice. Association for Supervision and Curriculum Development.

Danielson, C. (2014). The framework for teaching evaluation instrument (2nd ed.). Danielson Group.

Day, C., Gu, Q., \& Sammons, P. (2016). The impact of leadership on student outcomes: How successful school leaders use transformational and instructional strategies to make a difference. Educational Administration Quarterly, 52(2), 221-258. https://doi.org/10.1177/0013161X15616863

Demir, K. (2014). Teacher leadership culture scale: a study of validity and reliability. Elementary Education Online, 13(2), 334-344.

Demir, S. (2018). A Study on the relationship between school administrators' motivational language and teacher self-efficacy. Anemon Journal of Social Sciences of Muş Alparslan University, 6(2) 177-183. https://doi.org/10.18506/anemon.384848

Diamond, J. B., \& Spillane, J. P. (2016). School leadership and management from a distributed perspective: A 2016 retrospective and prospective. Management in Education, 30(4), 147-154. https://doi.org/10.1177/0892020616665938

Dilbaz-Sayın, S., \& Arslan, H. (2018). Öğretmen ve okul yöneticilerinin performans öz değerlendirme sonuçlarının okul kademesi ve mezuniyet değişkeni açısından incelenmesi. Ĭgdır Üniversitesi Sosyal Bilimler Dergisi, 16, 537-564.

DiRanna, K., \& Loucks-Horsley, S. (2001). Designing programs for teacher leaders: The case of the California science implementation network. ERIC Clearinghouse for Science, Math, and Environmental Education.

Donaldson, M. L., \& Johnson, S. M. (2007). Overcoming the obstacles of leadership. Educational Leadership, 65(1), 8-13. 
Dozier, T. (2007). Turning good teachers into great teachers. Educational Leadership, 65(1), 54-55.

Duyar, I., Gümüş, S., \& Bellibaş, M. S. (2013). Multilevel analysis of teacher work attitudes: the influence of principal leadership and teacher collaboration. International Journal of Educational Management, 27(7), 700-719. https://doi.org/10.1108/IJEM-09-2012-0107

Elliott, E. M., Isaacs, M. L., \& Chugani, C. D. (2010). Promoting self-efficacy in early career teachers: A principal's guide for differentiated mentoring and supervision. International Journal of Educational Administration and Policy Studies, 4(1), 131139.

Fernet, C., Trépanierb, S., Austin, S., Gagné, M., \& Forest, J. (2015). Transformational leadership and optimal functioning at work: on the mediating role of employees' perceived job characteristics and motivation. Work and Stress, 29(1), 11-31.

Field, A. (2005). Discovering statistics using SPSS. Sage Publication.

Frost, D. (2008). 'Teacher leadership': Values and voice. School Leadership and Management, 28(4), 337-352.

Gonzales, S., \& Lambert, L. (2001). Teacher leadership in professional development schools: Emerging conceptions, identities, and practices. Journal of School Leadership, 11(1), 6-24. https://doi.org/10.1177/105268460101100102

Graen, G. B. (1976). Role-making process within complex organization, in Dunnette, M. D. (Ed.), Handbook of industrial and organizational psychology (pp. 12011245). Rand Mcnally.

Gronn, P. (2000). Distributed properties: A new architecture for leadership. Educational $\begin{array}{llll}\text { Management } \quad \text { A } & \text { Administration, }\end{array}$ https://doi.org/10.1177/0263211X000283006

Guo, Y., Connor, C. M., Yang, Y., Roehrig, A. D., \& Morrison, F. J. (2012). The effects of teacher qualification, teacher self-efficacy, and classroom practices on fifth graders' literacy outcomes. The Elementary School Journal, 113(1), 3-24. https://doi.org/10.1086/665816

Guo, Y., Justice, L. M., Sawyer, B., \& Tompkins, V. (2011). Exploring factors related to preschool teachers' self-efficacy. Teaching and Teacher Education, 27(5), 961968.

Hallinger, P., Liu, S., \& Piyaman, P. (2017). Does principal leadership make a difference in teacher professional learning? A comparative study China and Thailand. Compare: A Journal of Comparative and International Education, 49(3), 341-357. https://doi.org/10.1080/03057925.2017.1407237

Herzberg, F., Mausner, B., \& Snyderman, B. (1959). The motivation to work. John Wiley.

Hipp, K. A., \& Bredeson, P. V. (1995). Exploring connections between teacher efficacy and principals' leadership behavior. Journal of School Leadership, 5, 136-150. https://doi.org/10.1177/105268469500500202

Hoy, W. K., \& Woolfolk, A. E. (1993). Teachers' sense of efficacy and the organizational health of schools. The Elementary School Journal, 93, 356-372. 
Hunzicker, J. (2012). Professional development and job-embedded collaboration: How teachers learn to exercise leadership. Professional Development in Education, $38(2), 267-289$.

Jackson, C. K., \& Bruegmann, E. (2009). Teaching students and teaching each other: the importance of peer learning for teachers. American Economic Journal: Applied Economics, 1(4), 85-108. https://doi.org/ 10.1257/app.1.4.85

Jacobson, S. (2011). Leadership effects on student achievement and sustained school success. International Journal of Educational Management, 25(1), 33-44. https://doi.org/10.1108/09513541111100107

Jöreskog, K. G., \& Sörbom, D. (1993). LISREL 8: Structural equation modeling with the SIMPLIS command language. Scientific Software International; Lawrence Erlbaum Associates.

Judge, T. A., Thoresen, C. J., Bono, J. E., \& Patton, G. K. (2001). The job satisfactionjob performance relationship: A qualitative and quantitative review. Psychological Bulletin, 127(3), 376-40. https://doi.org/10.1037/0033-2909.127.3.376

Kaçar, T., \& Beycioğlu, K. (2017). The investigation of elementary school teachers' self-efficacy beliefs in terms of various variables. Elementary Education Online, 16(4), 1753-1767. https://doi.org/ 10.17051/ilkonline.2017.342988

Kalaycı, Ş. (2014). SPSS uygulamalı çok değişkenli istatistik teknikleri. Ankara: Asil Yayınları.

Karaoğlu, İ. B. (2019). Adaptation of teacher sense of self-efficacy scale short form to Turkish: a study of validity and reliability. The Journal of Academic Social Science, 7(99), 123-139.

Katzenmeyer, M., \& Moller, G. (2009). Awakening the sleeping giant: Helping teachers develop as leaders. Corwin Press.

Kılınç, A. Ç., \& Recepoğlu, E. (2013). High school teachers' perceptions on and expectations from teacher leadership. Kalem Eğitim ve Insan Bilimleri Dergisi, $3(2), 175-215$.

Klassen, R. M., \& Tze, V. M. (2014). Teachers' self-efficacy, personality, and teaching effectiveness: A meta-analysis. Educational Research Review, 12, 59-76. https://doi.org/10.1016/j.edurev.2014.06.001

Korkmaz, M. (2005). Effects of leadership styles and emotions on teachers' performance. Educational Administration: Theory and Practice, 43, 401-422.

Kutluca, A. Y. (2018). Examination of teacher self-efficacy in terms of motivation and epistemological and pedagogical belief systems. Cumhuriyet International Journal of Education, 7(2), 175-192. https://doi.org/10.30703/cije.413053

Leithwood, K., Patten, S., \& Jantzi, D. (2010). Testing a conception of how school leadership influences student learning. Educational Administration Quarterly, 46(5), 671-706. https://doi.org/ 10.1177/0013161X10377347

Leonard, J., Petta, K., \& Porter, C. (2012). A fresh look at graduate programs in teacher leadership in the United States. Professional Development in Education, 38(2), 189-204. 
Lieberman, A., \& Friedrich, L. D. (2010). How teachers become leaders: Learning from practice and research. Teachers College Press.

Limon, İ., \& Sezgin-Nartgün, Ş. (2020). Development of teacher job performance scale and determining teachers' job performance level. Journal of Theoretical Educational Science, 13(3), 564-590. http://dx.doi.org/10.30831/akukeg.642340

Moore, W., \& Esselman, M. (1992, April). Teacher efficacy, power, school climate and achievement: A desegregating district's experience. In: Paper presented at the Annual Meeting of the American Educational Research Association, San Francisco.

Moss, S. E., Juan, I., Sanchez, J. I., Brumbaugh, A. M., \& Borkowski, N. (2009). The mediating role of feedback avoidance behavior in the LMX-Performance relationship. Group \& Organization Management, 34(6) 645-664. https://doi.org/10.1177/1059601109350986

Muijs, D., \& Harris, A. (2003). Teacher leadership-improvement through empowerment? An overview of the literature. Educational Management and Administration, 31(4), 437-448.

Neumerski, C. M. (2012). Rethinking instructional leadership, a review: What do we know about principal, teacher, and coach instructional leadership, and where should we go from here? Educational Administration Quarterly, 49, 310-347. https://doi.org/10.1177/0013161X12456700

Olsen, E. (2008). Helping teachers believe! An investigation into the relationship between principal leadership behaviors, organizational supports, and teacher efficacy belief [Unpublished doctoral dissertation]. University of California.

Onay, M. (2011). Çalışanın sahip olduğu duygusal zekâsının ve duygusal emeğinin, görev performansı ve bağlamsal performans üzerindeki etkisi. Ege Akademik Bakış, 11(4), 587-600.

Öntaş, T., \& Okut, L. (2017). The relationship between private elementary and middle school teachers' leadership behaviors and classroom management tendencies. Inonu University Journal of the Faculty of Education, 18(1), 98-115. https://doi.org/ 10.17679/inuefd.296131

Özdemir, M. (2014). Ĕ̆itim örgütlerinde insan kaynakları yönetimi. Anı Yayıncılık.

Özdemir, M., \& Gören, S. Ç. (2017). Mediating role of organizational commitment in leadership coherence, psychological empowerment and teacher performance relationship. Elementary Education Online, 16(1), 342-353. http://dx.doi.org/10.17051/io.2017.47449

Özdemir, M., \& Yirmibeş, A. (2016). Okullarda liderlik ekibi uyumu ve öğretmen performansı ilişkisinde iş doyumunun aracı etkisi. Gazi Eğitim Fakültesi Dergisi, 36(2), 323-348.

Özgenel, M., \& Aktaş, A. (2020). The effect of school principal's leadership styles on teacher performance. International Journal of Leadership Studies: Theory and Practice, 3(2), 1-18.

Özgenel, M., Mert, P., \& Parlar, H. (2020). Improving teacher performance: leadership qualities of school principals as a tool. Istanbul Commerce University Journal of Social Science, 39, 1127-1148. https://doi.org/10.46928/iticusbe.771119 
Öztürk, N., \& Şahin, S. (2017). Organizational culture and teacher leadership in educational organizations: mediation role of leader-member exchange. Elementary Education Online, 16(4), 1451-1468. https://doi.org/ 10.17051/ilkonline.2017.342967

Petrie, H. G. (Ed.). (1995). Professionalization, partnership, and power: Building professional development schools. State University of New York Press.

Pitts, D. (2009). Diversity management, job satisfaction, and performance: Evidence from U.S. Federal Agencies. Public Administration Review, March, 328-338.

Pounder, J. S. (2006). Transformational classroom leadership: The fourth wave of teacher leadership? Educational Management Administration \& Leadership, 34(4), 533-545. https://doi.org/10.1177/1741143206068216

Reeves, T. D., \& Lowenhaupt, R. J. (2016). Teachers as leaders: Pre-service teachers' aspirations and motivations. Teaching and Teacher Education, 57, 176-187. https://doi.org/10.1016/j.tate.2016.03.011

Robbins, S. P., \& Judge, T. A. (2012). Örgütsel davranış. Nobel Akademik Yayıncılık.

Saks, A. (1995). Longitudinal field investigation of the moderating and mediating effects of self-efficacy on the relationship between training and newcomer adjustment. Journal of Applied Psychology, 80(2), 211-225. https://doi.org/10.1037/0021-9010.80.2.211

Sawyer, J. M. (2005). A case study of teacher leadership as a strategy for implementing change [Unpublished doctoral dissertation]. Boston College.

Schunk, D. H., \& Ertmer, P. A. (1999). Self-regulatory processes during computer skill acquisition: Goal and self-evaluation influences. Journal of Educational Psychology, 91, 251-260. https://doi.org/10.1037/0022-0663.91.2.251

Sehgal, P., Nambudiri, R., \& Mishra, S. K. (2017). Teacher effectiveness through selfefficacy, collaboration and principal leadership. International Journal of Educational Management, 31(4), 505-517. https://doi.org/10.1108/IJEM-05-20160090

Shachar, H., \& Shmuelevitz, H. (1997). Implementing cooperative learning, teacher collaboration and teachers' sense of efficacy in heterogeneous junior high schools. Contemporary Educational Psychology, 22, 53-72. https://doi.org/10.1006/ceps.1997.0924

Skaalvik, E. M., \& Skaalvik, S. (2007). Dimensions of teacher self-efficacy and relations with strain factors, perceived collective teacher efficacy, and teacher burnout. Journal of Educational Psychology, 99(3), 611-625. https://doi.org/10.1037/0022-0663.99.3.611

Skaalvik, E. M., \& Skaalvik, S. (2010). Teacher self-efficacy and teacher burnout: A study of relations. Teaching and Teacher Education, 26(4), 1059-1069. https://doi.org/10.1016/j.tate.2009.11.001

Snoek, M., \& Volman, M. (2014). The impact of the organizational transfer climate on the use of teacher leadership competences developed in a post-initial master's program. Teaching and Teacher Education, 37, 91-100. http://dx.doi.org/10.1016/j.tate.2013.10.005 
Tabachnick, B. G., \& Fidell, L. S. (2013). Using multivariate statistics. Boston: Pearson.

Tims, M., Bakker, A. B., \& Derks, D. (2012). Daily job crafting and the self-efficacy performance relationship. Journal of Managerial Psychology, 29(5), 490-507. https://doi.org/10.1108/JMP-05-2012-0148

Tosuntaş, Ş. B. (2017). Factors that affect the interactive whiteboard usage of teachers and its effect on teacher performance [Unpublished doctoral dissertation]. Eskişehir Osmangazi University.

Tschannen-Moran, M., \& Hoy, A. W. (2001). Teacher efficacy: Capturing an elusive construct. Teaching and Teacher Education, 17, 783-805. https://doi.org/10.1016/S0742-051X(01)00036-1

Tschannen-Moran, M., \& Johnson, D. (2011). Exploring literacy teachers' self-efficacy beliefs: Potential sources at play. Teaching and Teacher Education, 27, 751-761. https://doi.org/10.1016/j.tate.2010.12.005

Tschannen-Moran, M., Woolfolk Hoy, A., \& Hoy, W. K. (1998). Teacher efficacy: its meaning and measure. Review of Educational Research, 68, 202-248. https://doi.org/10.3102/00346543068002202

Tuytens, M., \& Devos, G. (2012). The effect of procedural justice in the relationship between charismatic leadership and feedback reactions in performance appraisal. The International Journal of Human Resource Management, 23(15), 3047-3062.

Vigoda-Gadot, E. (2007). Leadership style, organizational politics, and employees' performance: an empirical examination of two competing models. Leadership Style, 36(5), 661-683. https://doi.org/10.1108/00483480710773981

Wahlstrom, K. L., \& Louis, K. S. (2008). How teachers experience principal leadership: The roles of professional community, trust, efficacy, and shared responsibility. Educational Administration Quarterly, 44(4), 458-495. https://doi.org/10.1177/0013161X08321502

Weightman, J. (2004). Managing people. Chartered Institute of Personnel and Development.

Wenner, J. A., \& Campbell, T. (2017). The theoretical and empirical basis of teacher leadership: A review of the literature. Review of Educational Research, 87(1), 134171. https://doi.org/10.3102/0034654316653478

Woessmann, L. (2011). Cross-country evidence on teacher performance pay. Economics of Education Review, 30, 404-418. https://doi.org/10.1016/j.econedurev.2010.12.008

Wolters, C. A., \& Daugherty, S. G. (2007). Goal structures and teachers' sense of efficacy: their relation and association to teaching experience and academic level. Journal of Educational Psychology, 99, 181-193. https://doi.org/10.1037/00220663.99.1.181

Yeung, K. W., \& Watkins, D. (2000). Hong Kong student teachers' personal construction of teaching efficacy. Educational Psychology, 20(2), 213-235.

Yiğit, Y., Doğan, S., \& Uğurlu, C. T. (2013). Teachers' views on teacher leadership behavior. Cumhuriyet International Journal of Education, 2(2), 93-105. 
York-Barr, J., \& Duke, K. (2004). What do we know about teacher leadership? Findings from two decades of scholarship. Review of Educational Research, 74(3), 255-316. https://doi.org/10.3102/00346543074003255

Zheng, X., Yin, H., \& Li, Z. (2018). Exploring the relationships among instructional leadership, professional learning communities and teacher self-efficacy in China. Educational Management Administration \& Leadership, 47(6), 843-859. https://doi.org/10.1177/1741143218764176 